\title{
THE FAME AND NOTORIETY OF DR. JOHN HUXHAM
}

\author{
by
}

\section{WILLIAM SCHUPBACH*}

JoHN HUXHAM, M.D., F.R.S., F.R.C.P. Edinburgh (c. 1692-1768), was an English physician whose practice was confined to Plymouth but whose writings were read throughout Europe. His literary career started with his Observationes de aere et morbis epidemicis (1739), in which meteorological records made at Plymouth from 1728 to 1737 were collated month by month with the diseases observed there. Further volumes followed the same plan from 1738 to 1748 , and from 1748 to 1752 . In these works there is a now conspicuous contrast between the meteorological records, which are elaborately quantified according to a scheme laid down by James Jurin, F.R.S., in 1723 , and the notes on morbidity and mortality, which are superficial and sometimes reduced to names of prevalent diseases. To do justice to the extensive medical knowledge which he acquired in compiling these observations, Huxham therefore published separate treatises on the Devonshire colic, on diphtheria, on smallpox, and his best-known work, An essay on fevers (1750), which was translated into Latin, French, and Italian. Here Huxham discussed the conditions under which fevers appeared, the different types of fevers, and the remedies which, according to his reasoning, should tend to cure them. Hippocrates, "the best and oldest master of our profession", 1 is the presiding genius of the work, but Sydenham and Huxham's teacher Boerhaave are also drawn on, and Huxham's own cases are introduced at intervals. $^{2}$

Huxham's writings must have been received with great interest, for they were published in London, Edinburgh, Amsterdam, Bremen, Munich, Paris, Venice, Naples, and Lisbon. A collected edition was published at Leipzig within the author's own lifetime, and two other editions of his collected works were published after his death. To the well-read European physician of the later eighteenth century, therefore, Huxham, though only a name, was a name regarded with the deepest respect. "Is there anyone", a Leipzig professor of medicine asked in 1764, "who has so much as

* William Schupbach, M.A., Keeper of Art Collections, Wellcome Institute for the History of Medicine, 183 Euston Road, London NW1 2BP.

$1 \mathrm{~J}$. Huxham, Observationes de aere et morbis epidemicis ab anno MDCCXXVIII ad finem anni MDCCXXXVII, Plymuthi factae, London, S. Austin, 1739, p. i, "optimus ille quidem artisque nostrae vetustissimus magister, Hippocrates".

${ }^{2}$ A brief survey of Huxham's life and writings was published by R. M. S. McConaghey, 'John Huxham', Med. Hist. 1969, 13: 280-287. My remarks on Huxham's publications are based on the holdings in the Wellcome Institute library. 


\section{William Schupbach}

hailed our art from the threshold, who has yet never heard the great name of HUXHAM?",

On turning to John Huxham's practice we find a very different picture. It has been said of Huxham that if we knew nothing of his published works "he might have seemed little more than a quack", 4 and the attitude of those at Plymouth who knew him not from his writings but in person was indeed far from respectful. Huxham was the subject of one of a series of biographical memoirs written by the nonconformist minister John Fox (1693-1763), who had known Huxham (also a nonconformist in religion) since their schooldays. ${ }^{3}$ In Fox's view, Huxham built up his practice by charlatanry. Having married money,

he began to look bigger, and to affect much more gravity than usual. And here was the beginning of that stiff and affected behaviour for which he hath been so very remarkable. He pretended to believe, that his awkward strut and an unnatural gravity would gain him respect, though he freely owned to me once, when I was speaking to him about it, that he laughed at himself for doing it: 'je moque de moi-mềme' was his expression. But dissimulation and hypocrisy were so natural to him, that he could wear any disguise, or make any outward profession, without seeming the least uneasy, or out of countenance, provided it contributed to his interest.

According to Fox, Huxham would assume importance by arranging to be called conspicuously out of church in order to attend fictitious patients. "For he was a man that seemed to be actuated in most parts of life by craft and treachery: he would do almost anything for his interest, and seemed to have very little regard for truth in anything that he said." Fox concludes that, while nothing could be said against Huxham's "morals", yet "he had neither honesty nor virtue to make him esteemed or respected".

This judgment seems too bad to be true, and it may have been motivated by Huxham's alleged desertion of Fox's church for the Established one, a move which

${ }^{3}$ G. C. Reichel (editor), I. Huxhami . . opera physico-medica, 2 vols., Leipzig, J. P. Kraus, 1764, vol. 1, fol. ${ }^{*} 5^{\bar{r}}$

‘ N. J. G. Pounds, 'John Huxham's medical diary', Loc. Popul. Studs., 1974, no. 12, pp. 34-37, p. 34.

'These memoirs were not published in Fox's or Huxham's lifetime. The MSS. were lent by a descendant of Fox to the editor of the Monthly Repository of Theology and General Literature, who published them in the volume for 1821, 16. The Huxham memoir appeared on pp. 505-506 under the title 'Biographical sketches of some of his contemporaries by Mr. John Fox'. The authenticity of this memoir was doubted by McConaghey (op. cit., note 2 above), who implied an ascription to James Northcote R.A., presumably on the ground that an account of Huxham which was virtually identical with that printed under Fox's name in 1821 was stated in 1832 to be derived from a memoir "given by the late Jas. Northcote, Esq. R.A. who had taken it from a manuscript written by an intimate friend of Huxham's" (Octavian Blewitt, The panorama of Torquay, 2nd ed., London, Simpkin \& Marshall, 1832, p. 262). However, this means simply that Northcote possessed transcripts of Fox's memoirs, as we know he did (W. Hazlitt, Conversations of James Northcote, Esq., R.A., London, H. Colburn, 1830, pp. 81-86, and Dictionary of national biography s.v. Northcote, James). These transcripts passed into the hands of Henry Woollcombe (Thos. Moore, The history of Devonshire, 2 vols. and a third of plates, London, R. Jennings, 1829-31, vol. 2, pp. 690-695), and thence to Plymouth library, where they were apparently destroyed in the second World War (letter to the present writer from Mr. J. R. Elliott, Central Library, Plymouth, 23 July 1979). Fox's original MSS. were to have been given after publication to Dr. Williams' Library, London, but they are not there now. The style of the Huxham memoir is indistinguishable from that of Fox's other works, such as his memoirs of Nathaniel Harding (Monthly Repository vol. cit., note 5 above, pp. 257-258) and Zachariah Mudge (cf. Hazlitt, op. cit., p. 86).

Northcote did not object to including Rennell's portrait of Huxham in his picture of the "Worthies of Devon", reproduced in Francis Russell, 'Devonshire connoisseur: the collection of Henry Woollcombe at Hemerdon', Country Life, 4 June 1981. 
would have profited his practice. ${ }^{6}$ However, Huxham's ill reputation with his contemporaries is also attested by an independent, oral tradition, which survived him by more than fifty years: for in 1832 the Plymouth antiquary Henry Woollcombe commented on Fox's memoir:

There are a great many anecdotes preserved of Huxham, all tending to corroborate the account here given of him [by Fox], for though he was unquestionably a man of talent, yet he was an instance of that strange admixture of character we constantly perceive in human nature. I abstain from mentioning them, because I hope some of them are overcharged; and I do not love to dwell on the imperfections of men, where there is real ability, as there was in this one.'

The present reason for dwelling on Huxham's mysterious notoriety is to explain the existence of the arresting, but otherwise incomprehensible, picture reproduced in Fig. 1. It is a painted portrait of a young woman (Fig. 4), defaced by a painting of a mezzotint engraving of a man. The painter has deliberately suppressed the identity of the man by depicting the bottom of the paper as rolled up over the sitter's name: we see only the qualification "M.D." and the name of the mezzotint engraver, "Fisher" (the Irish mezzotinter Edward Fisher, 1722-1785). The painting is first recorded in the possession of the family Mudge at Plymouth, and the traditional story of its origin is recorded on a nineteenth-century label on the back of the picture, as follows:

A picture with scroll over face by Hudson, Sir Joshua Reynolds Master. The original portrait was one of Miss Irons, a well-known beauty. When the picture came home she did not think it did her justice \& returned it to Hudson to have it improved. He painted over her face the scroll having the portrait of (?) Thomas Mudge saying he would put some sense into her head somehow \& that Thomas Mudge was the cleverest man he knew.

The plot seems plausible, in that such a disturbing defacement of the completed female portrait (Fig. 4) must have been caused by some offence which the sitter gave to the painter after he had finished the original portrait. However, of the three names recorded on the label, at least two are incorrect.

To take the painter first: Thomas Hudson (1701-1779), the master of both Reynolds and Wright of Derby, was a Devonian who portrayed many West Country sitters in the years 1730-1746. In 1741 he attended the meetings of the Governors of the Devon and Exeter Hospital at Exeter:9 governorship would presumably have entitled him and his household to receive medical treatment there, so it may be regarded as evidence of an intention to live in Devon. But in 1742 the portrait market in London changed in his favour, and he moved to the capital. ${ }^{10}$ Thereafter we have

6 William Munk, 'Biographia medica devoniensis. Part III', The western antiquary, 1886-7, 6: $258-262$. Although Munk acknowledges the help of an acquaintance of a friend of Huxham, all his information is derived from earlier writings, and in this case inferred from the fact, recorded by Blewitt (see previous note), that Huxham's body was buried in St. Andrew's, Plymouth.

${ }^{7}$ Blewitt, op. cit., note 5 above, p. 265.

- The picture is fully described in the exhibition catalogue Thomas Hudson 1701-1779: portrait painter and collector by Jacob Simon, with an introduction by Ellen G. Miles, London, Greater London Council (The Iveagh Bequest, Kenwood), 1979, no. 66. Unfortunately the right half of the label was lost when the picture was cleaned in 1979, after Mr. Simon had transcribed it. In the last line, the Kenwood catalogue errs in printing "wisest" for "cleverest", one of the words still present in part.

Ibid., fourth page of introduction and n. 14.

10 Ibid. 
few Devonshire portraits by Hudson. By the 1760s, when the Plymouth picture is dated on account of the woman's costume, Hudson was living in semi-retirement at Twickenham, and occupied in work for such eminent sitters as the Lord Chancellor, David Garrick, and the president of the Royal College of Physicians (Sir William Browne). His Devonshire connexions are therefore no reason to attribute the Plymouth picture to Hudson. The pose and the handling of the drapery are in any case untypical of a Hudson portrait.

Moreover, most professional portraitists were obliged to protect their careers by treating their sitters with a certain respect: one cannot conceive of Hudson, Reynolds, or any other successful artist of the time treating a customer with such spectacular contempt. Hogarth might be regarded as an exception, but he is ruled out as the painter of this picture by incompatibilities of time and place. The actual painter's name must therefore be provisionally regarded as lost. We would expect him to be a professional portraitist; probably trained in London; working in Plymouth (the home town of the Mudges) in the 1750s or '60s; and a man not likely to be worried by the prospect of insulting a client.

Equally implausible is the traditional identification of the sitter of the mezzotint portrait which conceals the woman's face. This sitter's name is followed by the letters "M.D.". Thomas Mudge (1717-1794), whose name is mentioned on the label, became celebrated as a maker of marine chronometers at Plymouth, but was never a doctor of medicine. His brother John Mudge (1720-1793) was indeed a doctor of medicine and a Fellow of the Royal Society, but among other discrepancies, he was blind and looked quite different when he was the same age as the sitter. The identification of the sitter as one of the Mudges must be due to a distortion of the tradition while the picture was in the hands of their descendants.

Despite the inaccuracy of the tradition, however, it is still possible to identify the sitter, and perhaps also the painter. For the mezzotint painted over the face of "Miss Irons" is undoubtedly intended to represent a mezzotint portrait of John Huxham, which was made by Edward Fisher (Fig. 2). The mezzotint is not explicitly dated, but it cannot have been printed before 1755, for the legend mentions Huxham's fellowship of the Royal College of Physicians of Edinburgh, which was awarded in that year."1 The "Miss Irons" portrait (as we now have it) cannot have been produced before 1755 either, for it was, of course, painted after the engraving of the mezzotint. Probably both the Huxham print and the "Miss Irons" picture were made not before 1758, the year of Fisher's earliest dated mezzotint. From the legend (Fig. 2) we know also that the mezzotint was engraved from a picture painted by an extremely obscure artist named Thomas Rennell; and this original portrait of John Huxham by Thomas Rennell can be seen today in the collection of the Royal Society of London, to which Huxham's son presented it in 1770, two years after the sitter's death (Fig. 3).

The suspicion naturally arises that Rennell may be the painter of the "Miss Irons" picture also. There is indeed a stylistic resemblance between the portrait of Huxham (Fig. 3) and the portrait of "Miss Irons" (Fig. 1): it is seen principally in the handling of the draperies. But that carries little weight, especially since the two portraits might

"Dictionary of national biography, s.v. Huxham. 


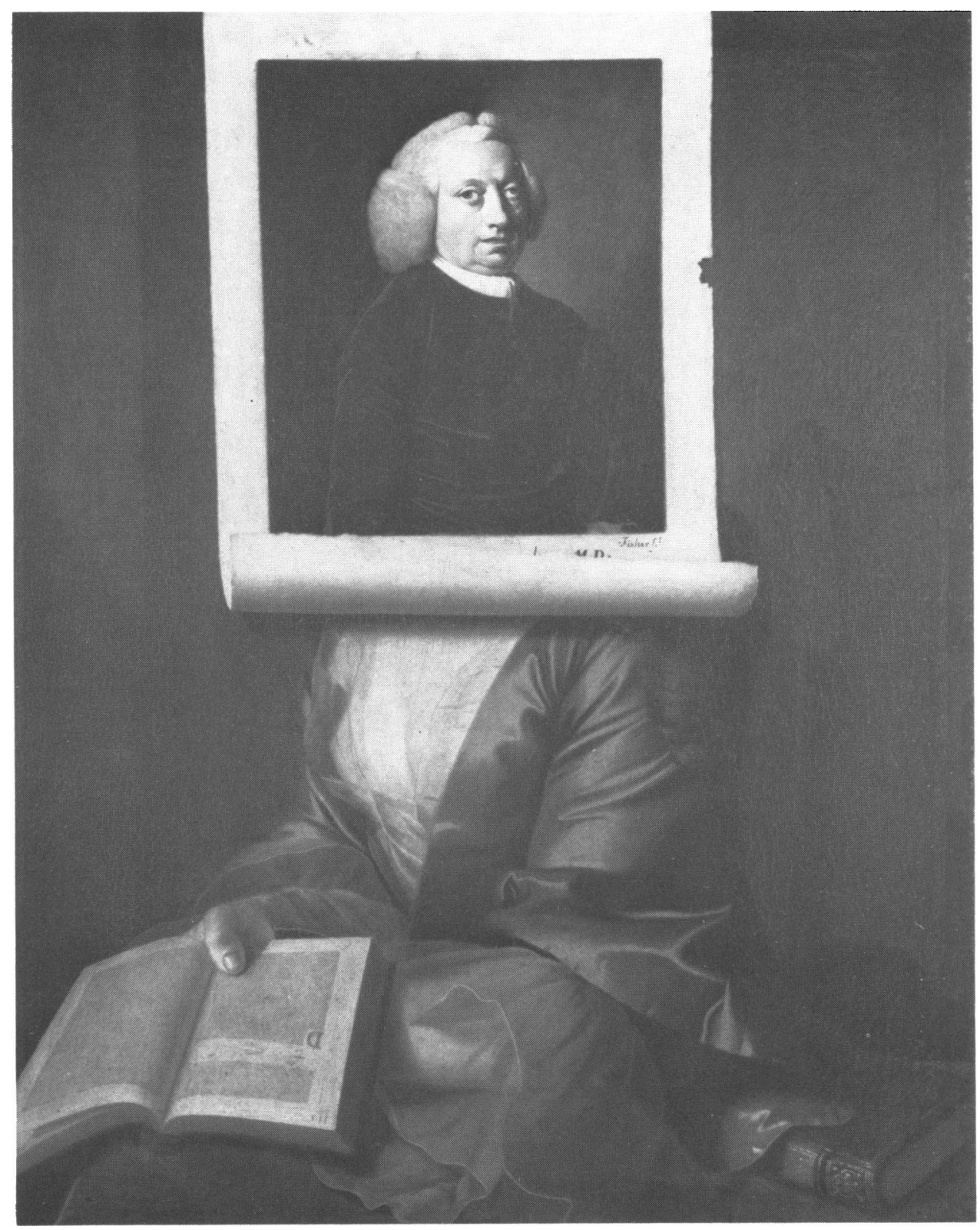

Figure 1. Oil painting on canvas, $75 \times 60 \mathrm{cms}$., attributed to Thomas Rennell, completed between $c .1758$ and 1788. Portrait of "Miss Irons" (?) with contemporary defacement. Property of Mr. A. H. Wright. Photo copyright Greater London Council, as trustees of the Iveagh Bequest, Kenwood. 


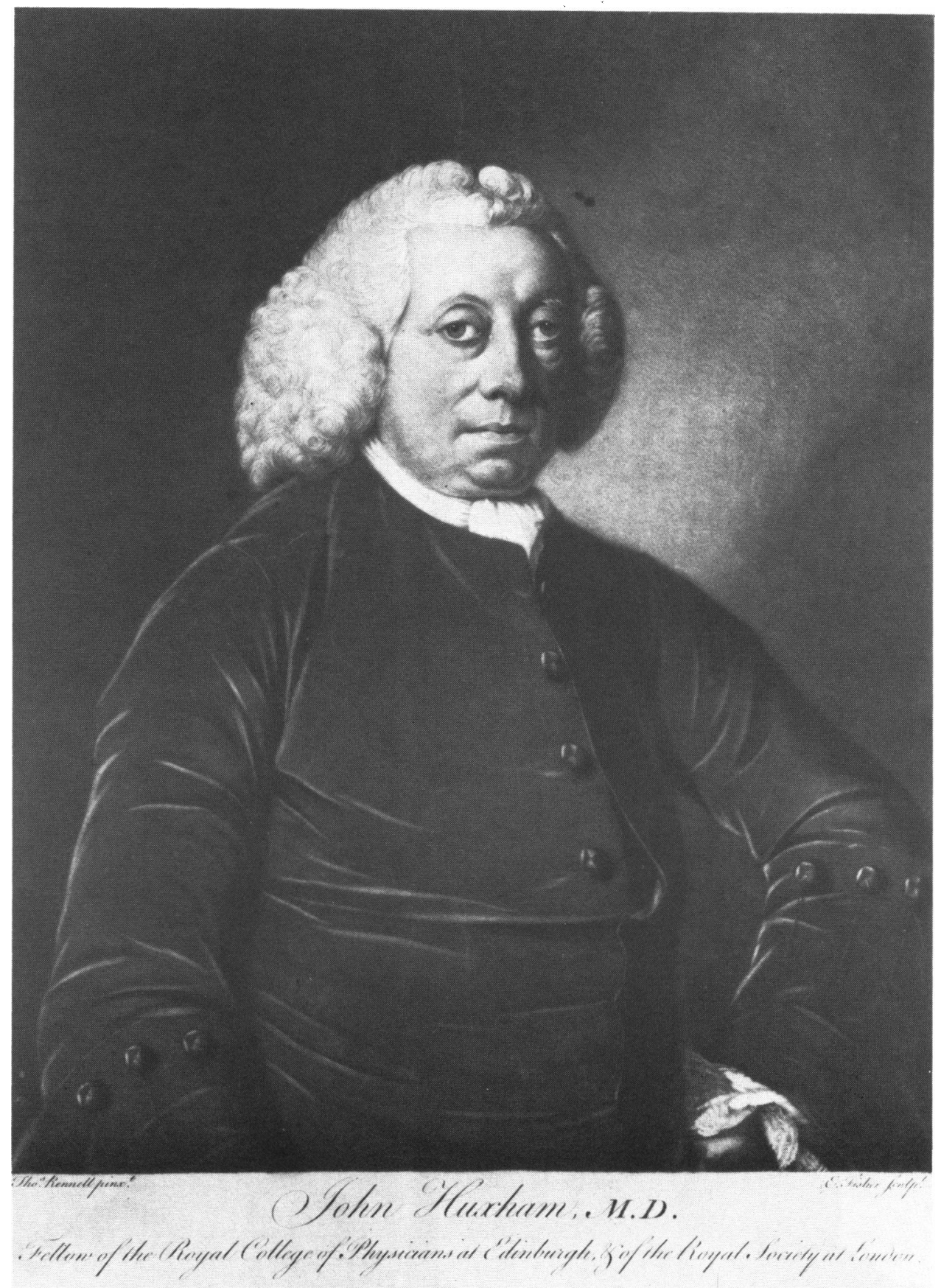

Figure 2. Mezzotint by Edward Fisher, made between $c$. 1758 and 1781 after the painting by Thomas Rennell reproduced in Fig. 3. Portrait of Dr. John Huxham. Wellcome Institute library, London (Renate Burgess, Catalogue of portraits of doctors and scientists in the Wellcome Institute for the History of Medicine, 1973, 1483.1). Reproduced by courtesy of the Wellcome Trustees. 


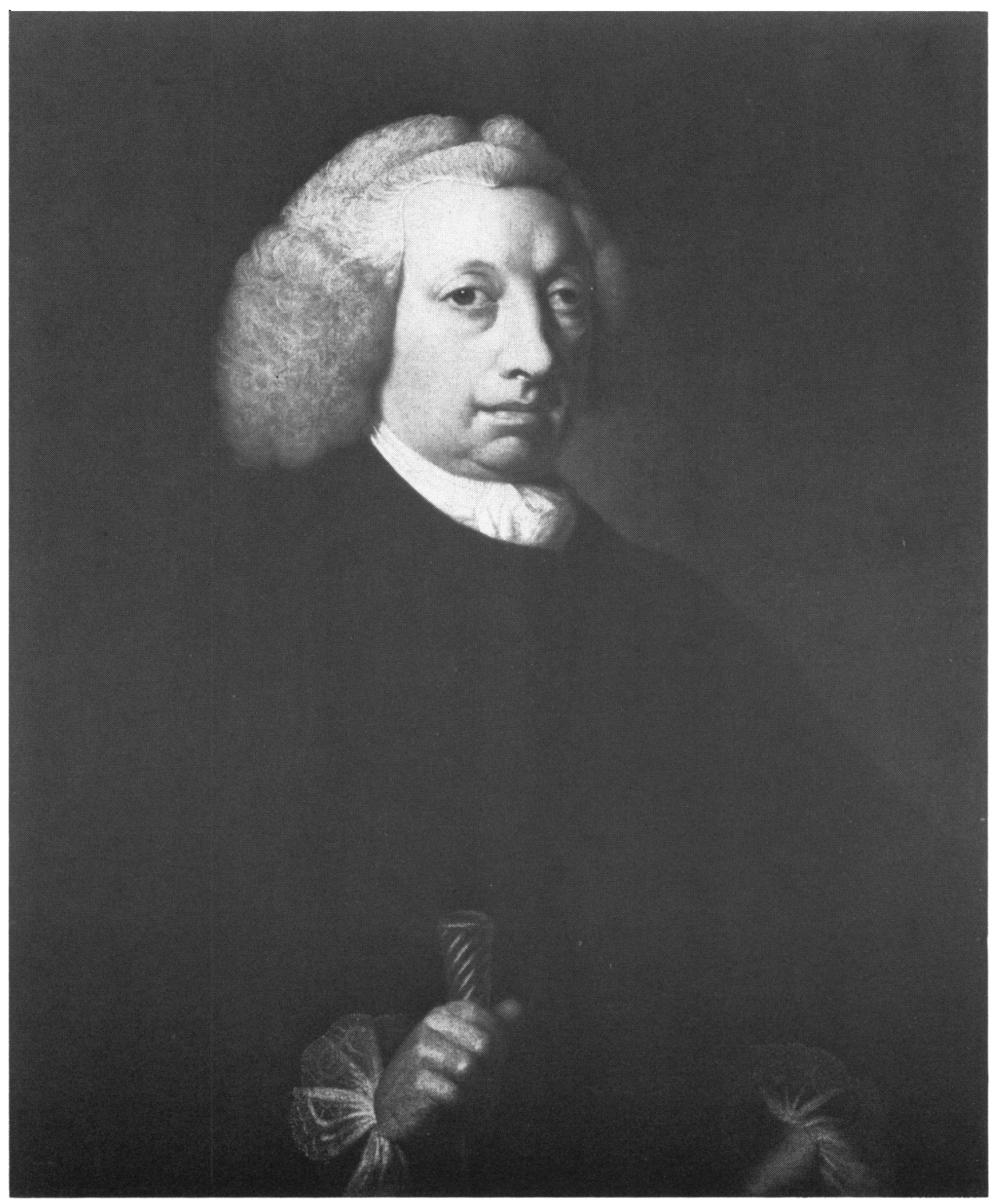

Figure 3. Oil painting on canvas, $76 \times 63 \mathrm{cms}$., by Thomas Rennell, painted before 1768. Portrait of Dr. John Huxham. The Royal Society of London. Reproduced by permission of the Chief Librarian, The Royal Society. 


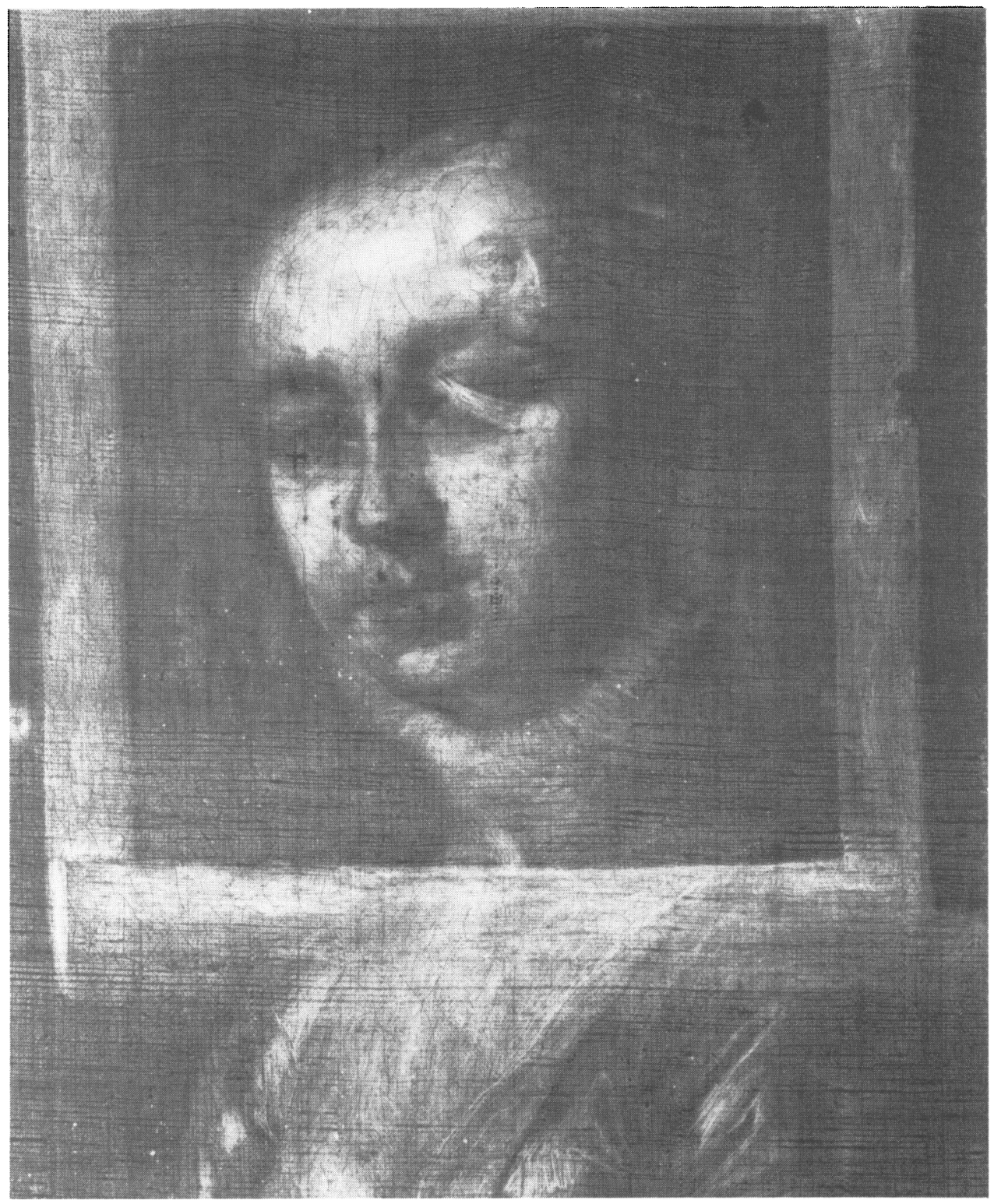

Figure 4. X-ray photograph: detail of Fig. 1. Head of "Miss Irons" (?), before defacement. The sitter is wearing a choker or a high collar. The later defacement is also visible. Photo copyright Greater London Council as trustees of the Iveagh Bequest, Kenwood. 
be separated in time by as much as twenty years. More important are Rennell's other qualifications, for they match exactly what we have postulated of the painter of the "Miss Irons" picture. According to the painter James Northcote, R.A., another native of Plymouth and virtually our only source of knowledge of him, ${ }^{12}$ Rennell was

a scholar of Hudson, some years previous to the time of Sir Joshua, who was born of a good family, long settled in that county [Devon], near Chudleigh, in the year 1718. After remaining some time at the grammar school of Exeter, he was put apprentice to Hudson, the painter, in London. How long he remained in that situation, I am not told, but at his return into Devonshire settled at Exeter with a wife and family. In process of time, he removed to Plymouth, where he resided many years, and drew several pictures, which were much admired in that neighbourhood and gained the painter the patronage of the Duke and Duchess of Kingston, who endeavoured to draw him from his obscurity, by a promise of their house and interest in London. But this splendid offer was lost in an indolent mind; and from Plymouth Rennell went to settle at Dartmouth, where he lived in great poverty several years. He has been known to lie in his bed for a week together, with no other subsistence than a cake and water. His art had only its turn with other amusements; and if a picture was completed in twelve months, it might be considered as very expeditious. No sooner was he in possession of a few pounds than any stray object that presented itself was instantly bought, though, by so doing, the necessaries of food and clothing were to be sacrificed. About two years before his death, he experienced a comfortable asylum in the bounty of J. Seale, Esq. of Dartmouth; and the manner of his end evinced his serenity, if not stoicism. Being asked whether his pains were not intense, he replied - "No, that they were such feelings as he could not describe, having never felt anything of the kind before:" then wishing his friend a good night, turned his head aside and expired, October 19th, 1788.

The knowledge of Mr. Rennell was universal; for there was hardly a science that did not come within the sphere of his comprehension. As a painter, he is said to have possessed merit, particularly in the draperies of his portraits. In the neighbourhood of Dartmouth are to be seen a few of his landscapes, but those very bad. He was very fond of chemistry, to which he devoted a considerable portion of his time. Most of his colours, which he prepared himself, went through that operation: and he is said to have discovered the art of fixing those which are the most fading. Of music he was passionately fond, and though not an excellent performer on any instrument, he composed some pieces which display genius. He also invented and constructed an instrument, containing sixty strings struck with a bow, moved by the foot, and modulated by keys. Some of his poetical pieces have been printed, ${ }^{13}$ but most of his papers were destroyed. Only one print has been taken from his works; to wit, a mezzotint scraped by Fisher: it is from a portrait of the eminent Dr. John Huxham, M.D., of Plymouth, and the only portrait ever done of that physician.

We can add only three minor points to this account. First, Rennell was born not in 1718, as Northcote's information had it, but in 1716: he was baptized at Chudleigh in Devon on 18 December 1716, the son of John and Mary Rennell. ${ }^{14}$ Second, he had returned to Plymouth from London by 1771 , and probably long before. ${ }^{15}$ Last, it is not certain that Rennell's portrait of Huxham was the only one: another is recorded, but its whereabouts are apparently unknown. ${ }^{16}$

It seems extremely unlikely that we shall find a second painter as well qualified as Thomas Rennell to have painted the bizarre portrait of " "Miss Irons" and Dr. Huxham'. The traditional story of the picture's origin is easily accounted for. For the name of the obscure Thomas Rennell was substituted the name of the more

${ }^{12}$ James Northcote, Supplement to the memoirs of the life, writings, discourses and professional works of Sir Joshua Reynolds, Knt., London, H. Colburn, 1815, pp. v-vi.

${ }_{13}$ Untraced.

${ }^{14}$ Information from Chudleigh parish registers, kindly communicated by Miss J. V. Boundy.

$15 \mathrm{~W}$. T. Whitley, Artists and their friends in England 1700-1799, 2 vols., London, The Medici Society, 1928, vol. 2, p. 283, quotes a letter from J. Northcote in London to his brother Samuel in Plymouth, dated 21 September 1771: "I would not have you mention to Rennell anything of what I may have said concerning Sir Joshua ...".

${ }^{16}$ Recorded by Blewitt, op. cit., note 5 above, p. 265. 


\section{William Schupbach}

famous local painter Thomas Hudson. When the picture was in the Mudge collection, the name of the sitter, John Huxham, was perhaps replaced by the more familiar John Mudge, then turned into Thomas Mudge either under the influence of the other Thomases or because Thomas Mudge's appearance was known from other portraits to be less unlike the sitter's than his brother's was. ${ }^{17}$ Of course, all these Plymouth citizens were known to each other. Huxham commissioned Rennell to paint his portrait. Rennell and the Mudges were mutual acquaintances of Samuel Northcote..$^{18}$ John Mudge claimed to have cured a convulsive patient whom Huxham had treated without success. ${ }^{19}$ These connexions account for the Mudge provenance of the " $" M i s s$ Irons" and Dr. Huxham' picture, here attributed to Rennell (Fig. 1).

But, when the picture belonged to the Mudges, was it only the names that were changed? Names have connotations which colour their context, and in this case it may be that the Mudge provenance has caused a drift in the entire narrative. According to the Mudge tradition, the painter decided to "put some sense into her head somehow", and therefore the man whose face he substituted (who was then wrongly identified with a Mudge) was "the cleverest man he knew". But if we look at the picture itself, and forget the unreliable tradition, the introduction of the mezzotint with the sitter's name suppressed seems anything but complimentary to him. To "Miss Irons" also, if the reason for her objection is correctly reported, this anonymous, wall-eyed figure cannot have seemed a very appealing personification of wisdom. The defacement looks more like an insult than a lesson, and it is indeed one of the traditional practices of painters to insult their bad customers in public by defacing their rejected commissions in ingeniously appropriate ways. ${ }^{20}$ The picture therefore suggests a different interpretation: that the painter's intention was not to improve "Miss Irons" with the features of a paragon of virtue, but to brand her with the image of a notorious blackguard. This hypothesis, unlike the Mudge tradition, has the advantage of drawing together four independent strands in the argument: the secure identification of the mezzotint-sitter as Huxham; Huxham's reputation at Plymouth; the unconventional character of the proposed painter, Thomas Rennell; and what the finished picture suggests about the motive for the defacement.

The specific reason for the insertion of Huxham's portrait would depend on the reason for "Miss Irons" 's objection. If she really did object, as the label says, that the portrait did not "do her justice", Huxham's portrait would have been inserted, according to the logic of the situation, for its ugliness. But if the painter was more annoyed at the cancellation of a completed commission, then we are reminded of Fox's allegation that Huxham "was actuated in most parts of life by craft and treachery". As long as nothing more is known of "Miss Irons" than a name on a label

\footnotetext{
17 The appearances of both brothers Mudge are known through engravings, and Reynolds' portrait of John Mudge was in the same collection as the "Miss Irons" portrait until 1958.

18 For Rennell and S. Northcote see note 15 above. Samuel Northcote and Thomas Mudge were in the same business at Plymouth (watch-making), and John Mudge was the principal patron of James Northcote - see the latter's writings, passim.

19 John Mudge, $A$ radical and expeditious cure for a recent catarrhous cough ..., London, E. Allen, and Plymouth, M. Haydon, 1779, pp. 56-58.

${ }^{20}$ E. Kris and O. Kurz, La leggenda dell' artista, Turin, Boringhieri, 1980, pp. 100-101.
} 
that has proved to be unreliable, there can be no reason for preferring one explanation to the other.

Huxham need not have worried. His scientific prestige abroad would prove almost sufficient to silence his detractors' attacks at home. In Leipzig he was being trumpeted as "that most outstanding author and sagacious researcher, the wisest and most prudent physician, HUXHAM". ${ }^{21}$ In the course of time, the quality, quantity, and latinity of his published works transformed the gibes of his contemporaries into a solemn Victorian eulogy: for in the words of the Victorian biographer of English physicians, William Munk, Huxham "by a life of unimpeachable correctness ... obtained universal respect".22

${ }^{21}$ Reichel, loc. cit., note 3 above.

${ }^{22}$ Munk, op. cit., note 6 above, p. 260. For those who use Munk's Roll of the Royal College of Physicians of London, it is instructive to see how he came to this statement. It is a heightened version of Thomas Moore's statement (loc. cit., note 5 above) that Huxham "by a life of unimpeachable morals obtained general respect". Munk has promoted "morals" to "correctness" and "general" to "universal". Moore's account of Huxham is merely a paraphrase of Fox (as his account of Rennell is of Northcote), so his statement in turn is no more than a heightened version of Fox's concession that Huxham "kept a decent character with regard to his morals". Thus Fox's damnation of Huxham was transformed into Munk's hagiography. 